Int. J. Electrochem. Sci., 12 (2017) $3697-3708$

\title{
Towards an Efficient Direct Glucose Anion Exchange Membrane Fuel Cell System with Several Electro-Oxidation Units
}

\author{
Spets Jukka-Pekka ${ }^{1, *}$, Kanninen Petri ${ }^{2}$, Kallio Tanja ${ }^{2}$, Selkäinaho Jorma ${ }^{3}$, Kiros Yohannes ${ }^{4}$, \\ Saari Kari ${ }^{1}$, Larmi Martit ${ }^{1}$ \\ ${ }^{1}$ Dept. Mechanical Engineering, School of Engineering, Aalto University, Espoo, P.O. Box 14400, FI- \\ 00076 Aalto, Finland \\ ${ }^{2}$ Dept. Chemistry and Material Science, School of Chemical Engineering, Aalto University, Espoo, \\ P.O. Box 16100, FI-00076 Aalto, Finland \\ ${ }^{3}$ Dept. Electrical Engineering and Automation, School of Electrical Engineering, Aalto University, \\ Espoo, P.O. Box 15500, FI-00076 Aalto, Finland \\ ${ }^{4}$ Dept. Chemical Engineering and Technology, KTH Royal Institute of Technology, SE-100 44 \\ Stockholm, Sweden \\ *E-mail: jukka-pekka.spets@aalto.fi
}

doi: $10.20964 / 2017.05 .41$

Received: 13 February 2017 / Accepted: 19 March 2017 / Published: 12 April 2017

This work covers the direct glucose anion exchange membrane fuel cell (AEMFC) with near-neutralstate electrolyte of $0.1 \mathrm{M}^{0}\left[\mathrm{PO}_{4}\right]$ tot having two high-performing anode electrocatalysts (Pt and $\left.\mathrm{PtNi}\right)$ at $37{ }^{\circ} \mathrm{C}$ and at a glucose concentration of $0.1 \mathrm{M}$. The cathode catalyst in each test was a Pt supported on carbon $(60 \mathrm{wt} . \%)$. The PtNi/C had a total metal content of $40 \mathrm{wt} . \%$ and the $\mathrm{Pt} / \mathrm{C} 60 \mathrm{wt} . \%$. The operation of the AEMFC was controlled by means of an in-house made electronic load with PIcontroller (i.e. a feedback controller, which has proportional and integral action on control error signal). There were two primary objectives with this study. At first, to find out how the electrode modifications of the anode (i.e. by increasing the thicknesses of these electrodes by adding extra carbon) affect the Coulombic efficiency (CE, based on the exchange of two electrons) and the specific energy (SPE, Wh kg${ }^{-1}$ ) values of the direct glucose AEMFC. Secondly, investigate how a two-stage fuel cell system with two fuel cells concatenated and used one after the other for the electrochemical oxidation of glucose, influence the CE and SPE values. The results show that the modified PtNi anode shows superior results for the AEMFC compared to our earlier results. As for the two-stage fuel cell system, it increased the average electric power $(\mathrm{mWh})$ and SPE when compared to single fuel cell systems except when the higher selective anode catalyst $(\mathrm{Pt})$ was used in the first fuel cell prior to the fuel cell in the second fuel cell containing the lower selective anode catalyst (PtNi). 
Keywords: glucose, anode electrocatalysts, anion exchange membrane fuel cell, near-neutral-state electrolyte, multistage fuel cell system

\section{FULL TEXT}

(C) 2017 The Authors. Published by ESG (www.electrochemsci.org). This article is an open access article distributed under the terms and conditions of the Creative Commons Attribution license (http://creativecommons.org/licenses/by/4.0/). 